Article

\title{
Agroforestry Practices in Livelihood Improvement in the Eastern Cape Province of South Africa
}

\author{
Mulatu Fekadu Zerihun
}

Citation: Zerihun, M.F. Agroforestry Practices in Livelihood Improvement in the Eastern Cape Province of South Africa. Sustainability 2021, 13, 8477. https://doi.org/10.3390/su13158477

Academic Editor: Andres Seco

Meneses

Received: 18 May 2021

Accepted: 5 July 2021

Published: 29 July 2021

Publisher's Note: MDPI stays neutral with regard to jurisdictional claims in published maps and institutional affiliations.

Copyright: (C) 2021 by the author. Licensee MDPI, Basel, Switzerland. This article is an open access article distributed under the terms and conditions of the Creative Commons Attribution (CC BY) license (https:/ / creativecommons.org/licenses/by/ $4.0 /)$.
Department of Economics, Faculty of Economics and Finance, Tshwane University of Technology, Pretoria 0183, South Africa; Zerihunmf@tut.ac.za

\begin{abstract}
Agroforestry plays a significant role in increasing agricultural productivity. In South Africa, there is a pressing need for promoting smallholder agriculture to promote sustainable rural livelihoods, to ensure food security, to lower inflation in food prices, and address rampant rural unemployment in the country. The agricultural economy is characterised by a monopoly structure where almost every single staple in South Africa is already produced by large manufacturers that can produce it at better quality and lower cost than the average smallholder enterprise or cooperative. Such a monopoly structure fundamentally undermines the development of local markets, where local small-scale producers sell to their local community. The novelty of this study is addressing the research gap that conventional rural livelihood analyses often neglect, i.e., the role of environmental products in general, and forest and agroforestry products. Using a log linear regression model with cross-sectional data collected from a sample of 300 households, this study explores the likely impact of agroforestry practices in promoting the livelihood of rural communities in the study areas. Results obtained from multiple linear regression analysis showed that average household income increased as a function of utilization of agroforestry practices. Agroforestry contributes to sustainable rural livelihoods in South African provinces where the predominant means of livelihoods is rural subsistence farming and agriculture. Since valuation of agroforestry products and services are technically difficult, farmers often underestimate the contribution of agroforestry to the household's livelihood income. These findings have policy implications in promoting food security in the Eastern Cape Province of South Africa and beyond.
\end{abstract}

Keywords: agroforestry; food security; sustainable livelihood; South Africa

\section{Introduction}

Farmers' livelihood improvements are often associated with land-based economic development strategies [1]. Land-based rural development strategies such as agroforestry and advanced extension services are believed to improve the livelihood of rural farming households [2]. A recent study by Ahmed et al. [3] explores livelihood improvement through agroforestry compared to conventional farming systems and finds a mixed impact on five types of capital, namely human, physical, natural, financial, and social. A study by Oduniyi et al. [4] set a stride in climate change awareness leading to mitigation strategies using agroforestry practices as an option to be used in the rural farming area of South Africa. Agroforestry is defined as 'a land use that involves deliberate retention, introduction, or mixture of trees or other woody perennials in crop or animal production fields to benefit from the resultant ecological and economic interactions' [5,6]. Agroforestry practices have considerable potential in helping solve some of Africa's land-use problems $[7,8]$ through provision of a wide range of tree products for domestic use or sale [9]. Agroforestry plays a significant role in increasing agricultural productivity by nutrient cycling, reducing soil erosion, improving soil fertility, and enhancing farm income compared to conventional crop production [10-13]. However, the increasing realization of agroforestry as an environmentally and economically suitable land use and its economic potential as a competing land use from private and social perspectives have not been thoroughly studied $[11,12,14]$. 
Agroforestry can also potentially reduce deforestation while increasing food, fodder, and fuel wood production $[11,12,15]$. Different land uses exert different levels of costs and benefits to society by generating externalities such as soil erosion and environmental degradation. It is, therefore, important for policymakers to know which land-use systems better serve to improve the livelihood of rural people as well as mitigate adverse environmental effects that motivate farmers to move from unsustainable to sustainable land-use practices [16]. Benefits that accrue from usage of agroforestry include food and nutrition security, increased income and assets, and improved land management [17] it also creates environmental and management synergies [18,19].

In South Africa, there is a pressing need for promoting smallholder agriculture to promote rural livelihoods, to ensure food security, to lower higher inflation in food prices, and address rampant rural unemployment in the country. Studies have shown that the number of households engaging in subsistence agriculture as a main source of food and income is declining, while there are underutilized agricultural resources (especially communal land in former homeland areas). Meanwhile, there is a rise in the number of households engaging in subsistence production as an extra source of food $[20,21]$. The Department of Agriculture's policy document on an integrated food security strategy notes that the government realises the importance of food security and therefore prioritises expenditure to benefit the historically disadvantaged groups. To comprehend the likely impact of the neglect of smallholder agriculture and its components such as agroforestry on food availability, the respondents in the study area were asked to comment on food availability and related questions.

The Eastern Cape is one of the poorest provinces of the country. Agroforestry can contribute to sustainable rural development in South Africa's provinces where the predominant means of livelihoods is rural subsistence farming and agriculture. Agroforestry practices comply with environmental guidelines while enabling subsistence and small-scale farmers to improve their yield per plot of land. As such, the broader theme of the study was about the effective utilization of natural resources such as the promotion of agroforestry that can contribute to sustainable rural livelihoods. Although agroforestry practices have been shown to have the potential for improving productivity and livelihoods among rural farmers in most of the world's developing nations, very little effort has been made in South Africa irrespective of the vast potential for agroforestry [4,22].

The objective of this study is to analyse the likely impact of agroforestry practices in promoting the livelihood of rural communities in Tsolo and Lusikisiki, in the O.R. Tambo district of Eastern Cape Province of South Africa (see Figure 1). The types of agroforestry practices in the study areas include farming of livestock alongside trees and crops (silvopasture), hedges, woodlots, live fences, and fruit trees near houses. This objective is consistent with the strategic priorities of the South African Department of Agriculture, Land Reform, and Rural Development. The findings in this study show positive and significant contributions of agroforestry practices to the rural livelihood in the study area. The remaining sections of the paper are organized as follows. Section 2 briefly presents the literature and conceptual framework for agroforestry livelihood analysis. Section 3 presents the data and methodology used in the study, while Section 4 presents the results and discussion of relevant issues in the study areas and empirical findings of the study. The last section concludes the study. 


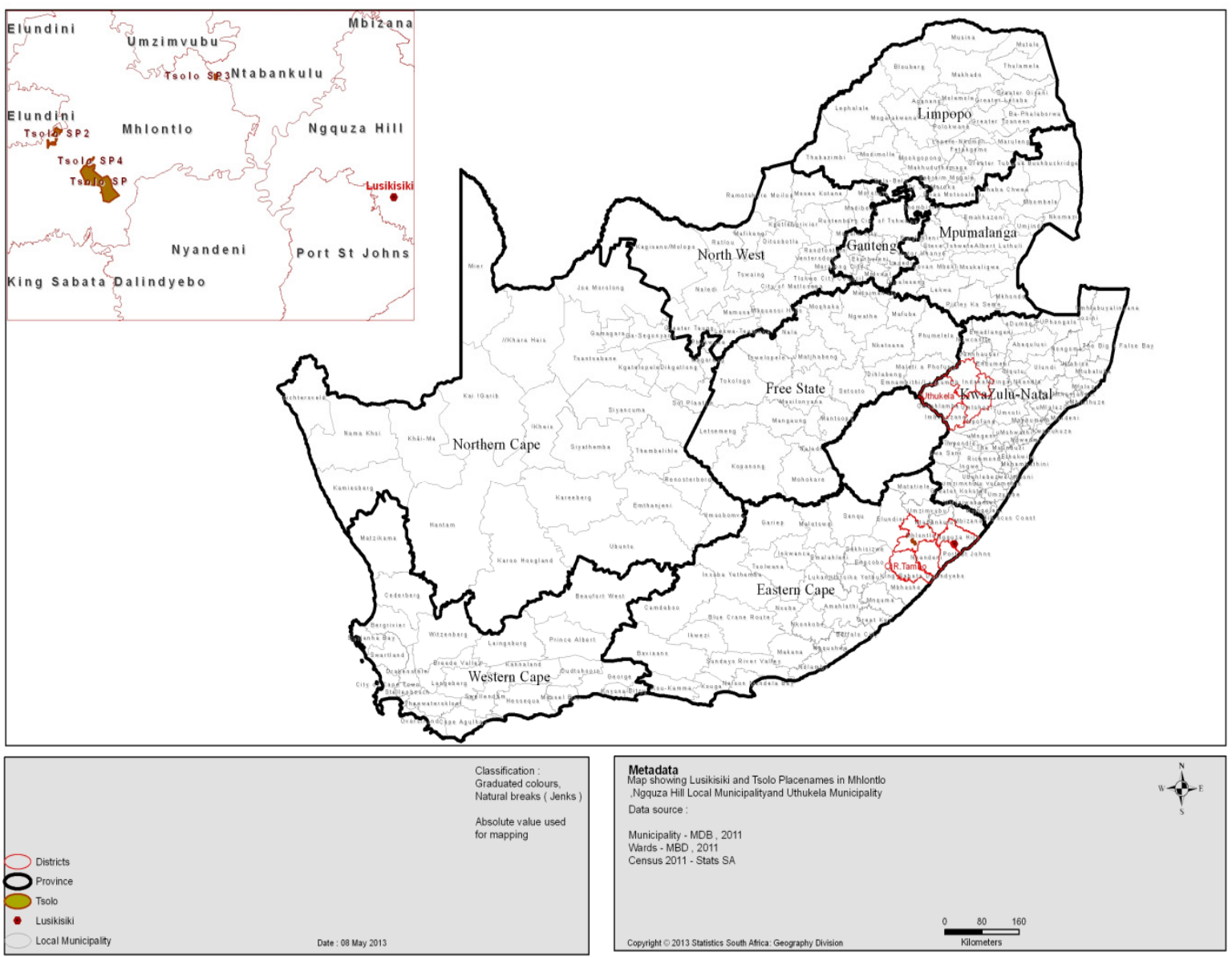

Figure 1. Map of the study sites (the study sites highlighted in red).

\section{Literature Review and Conceptual Framework}

\subsection{Agroforestry and Livelihoods}

Conventional rural livelihood analyses often neglect the role of environmental products in general, and forest and agroforest products, in particular [23]. However, traditional agroforestry has been practiced for millennia by agrarian-based societies throughout the world [17]. The World Bank estimates that 1.2 billion people practice some form of agroforestry on their farms and in their communities [24]. Although agroforestry has been practiced by these farming communities for a long time, there is inadequate awareness about its potential to the millions that live in poverty [17].

In recent days, agroforestry has progressed as a science-based pathway for achieving important objectives in natural resource management and poverty alleviation [17]. There is increasing evidence that the potential of agroforestry to reduce poverty is real and can be put to efficient use in poverty reduction strategies of many countries in Africa. In forestscarce countries, agroforestry has expanded greatly on small farms. In Kenya and Ethiopia, for example, farms account for most timber and pole production [1,25]. In agroforestry systems, the cost of tree production may be lower due to joint production with crops and livestock. Trees may even have a positive effect on the incomes of associated crops, as in the case of windbreaks [1].

According to Alavalapati and Mercer [26] and Alavalapati and Nair [27], agroforestry practices range from traditional to modern practices. The nature, complexity, and objectives also vary greatly between the agroforestry practices in the tropics and temperate zones. There are eight major agroforestry practices in tropical system. First, the 'taungya' system refers to agricultural crops grown during the early stages of forest plantation establishment $[26,27]$. The term agroforestry replaced the term taungya, a local term of 
Myanmar meaning "cultivation on hillsides" [28]. Second, home gardens refer to intimate, multistorey combinations of a variety of trees and crops in homestead gardens (livestock may or may not be present). Third, improved fallow refers to fast growing, preferably leguminous woody species planted during the fallow phase of shifting cultivation. Fourth, multipurpose trees refer to fruit and other trees randomly or systematically planted in cropland or pasture for the purpose of providing fruit, fuel wood, fodder, and timber, among other services, on farms and rangelands. The fifth is the combination of plantation and agricultural crops that integrate multistorey mixtures of trees and crops (such as coconut, cacao, coffee, and rubber), shade trees, and crops $[29,30]$. The sixth one is called 'silvopasture', which is the practice of combining trees with forage and livestock production, such as grazing in existing forests; using trees to create live fences around pasture; or to provide shade and erosion control. Seventh, shelterbelts and windbreaks that refer to rows of trees around farms and fields planted and managed as part of crop or livestock operations to protect crops, animals, and soil from natural hazards including wind, excessive rain, seawater, or floods. Lastly, alley cropping combines fast-growing, preferably leguminous woody species into single or grouped rows, which are applied as mulch into the agricultural production alleys to increase organic matter and nutrients and/or are removed from the field for other purposes such as animal fodder [31].

\subsection{Conceptual Framework for Livelihoods Analysis}

A study by Babulo et al. [23] used the sustainable livelihoods approach as a framework of analysis to identify the factors that influence a household's choice of a livelihood strategy, with a particular focus on the extraction of, and dependence on forest products in Tigray, Ethiopia. This study extends the previous study by including forestry services, particularly income derived from agroforestry products and services in household livelihood strategies. Similarly, Brown et al. [32] used an asset-based approach that identified distinct livelihood strategies in a household survey in Kenya's central and western highlands. This study adapts the five capitals used in the Department for International Development (DFID) livelihood framework [33]: human, natural, physical, financial, and social capitals as defined below.

\subsubsection{Human Capital}

Human capital is considered as one of the basic building blocks or means of achieving livelihood outcomes [34]. At the farm household level, human capital is a factor of the amount and quality of labour available; this varies according to household size, education level, skill levels, and health status.

\subsubsection{Natural Capital}

Natural capital comprises land, water, rivers, forests, and other biological resources that people utilise to generate a livelihood. One of the principal physical natural resources for farmers' livelihoods is land, and any decision related to land use would be affected by their access to land and security of tenure [35].

\subsubsection{Financial Capital}

Financial capital has been used to refer to the stock of money that the household has access to [34]. These include savings held in the bank, credit, stocks, and fungible assets such as jewellery, gold, or food stocks. At the farm household level, financial capital refers to savings held in the bank, access to credit in the form of loans, and stocks. Financial capital only becomes a useful asset in the household when it is converted into other forms of capital or is used directly for the purchase of food or agricultural inputs. This ease of switching between uses makes financial capital one of the fundamental assets [34]. 


\subsubsection{Physical Capital}

This refers to basic infrastructure such as transport, shelter, water, energy, communications, and production equipment, which enable people to pursue their livelihoods. At the household level, farm equipment, housing, livestock (used for animal traction), and other personal household properties that can be converted into cash are considered as physical capital [36].

\subsubsection{Social Capital}

Various definitions of social capital have been offered. According to the World Bank (2002), social capital refers to features of social organisation, such as networks, norms, and trust that facilitate coordination and cooperation for mutual benefit. Sun et al. [37] and Narayan [38] (1997:50) highlight the components of social capital as the rules, norms, obligations, reciprocity, and trust embedded in social relations, social structures, and society's institutional arrangements, which enable its members to achieve their individual and community objectives. Jeremy [39] defined social analysis as a generic term which encompasses institutional, political, and social analyses.

The livelihood framework focuses on households' access to five types of 'capital' or 'assets'- natural, human, physical, social, and financial [23]. It presents the basic framework of the dependence of activity choice on assets. For details on the basic framework, see Babulo et al. [23]. The livelihood approach is based on the premise that the resource and asset status of people is fundamental to understanding the options open to them, the strategies they adopt to attain livelihoods, the outcomes they aspire to, and the vulnerability context under which they operate [34].

\section{Materials and Methods}

\subsection{Study Area}

The Eastern Cape Province is situated in the southeastern part of South Africa. The dominant land use in the majority of the Eastern Cape is grazing, along with dry-land agriculture in the eastern section of the province. Agriculture in the Eastern Cape is dominated by intensive beef and fruit farming in the southwestern parts, and subsistence farming (mainly of cattle, maize, and sorghum) in the northeastern regions. The southern coastal area is conducive to forestry. However, the Eastern Cape faces several environmental threats, chief among them, land degradation. It exhibits high levels of soil degradation, particularly in commercial farmland areas. In other areas, the thicket biome is threatened by invasive alien species and overgrazing by domestic herbivores [40]. The two study sites Tsolo and Lusikisiki are in the O.R. Tambo district of Eastern Cape Province of South Africa as depicted in Figure 1.

\subsection{Research Method}

Data were collected from the Tsolo and Lusikisiki Magisterial Districts of the Eastern Cape Province using a pretested, validated, and standardized questionnaire. The survey was conducted from December 2011 up to June 2012. These two sites were selected on account of the existence of noticeable agroforestry practices in the areas. As used in recent studies [41,42], semi structured interviews were conducted with adult household heads. A total of 300 respondents were included in the semistructured interviews, of which 53 percent are females and 43 percent are males. In addition to the "yes" or "no" questions presented in Table 1, the survey questions include data on annual income from crops and horticultural produces, farm production costs, monetary value of agroforestry products and services, livestock size, and household size. These data were collected from sampled households in the study areas. 
Table 1. Main sources of livelihood in Tsolo and Lusikisiki, respectively.

\begin{tabular}{|c|c|c|c|c|c|c|}
\hline \multirow{3}{*}{$\begin{array}{l}\text { Do You Get Income from } \\
\text { Agricultural Activities? }\end{array}$} & \multicolumn{6}{|c|}{ District } \\
\hline & \multicolumn{2}{|c|}{ Tsolo } & \multicolumn{2}{|c|}{ Lusikisiki } & \multicolumn{2}{|c|}{ Total } \\
\hline & Col \% & $\mathbf{N}$ & Col \% & $\mathbf{N}$ & Col \% & $\mathbf{N}$ \\
\hline No & 68 & 81 & 69.5 & 98 & 68 & 179 \\
\hline Yes & 32 & 38 & 30.5 & 43 & 31.2 & 81 \\
\hline Total & 100.0 & 119 & 100.0 & 141 & 100.0 & 260 \\
\hline \multicolumn{7}{|c|}{ Do you get income from livestock sell? } \\
\hline No & 86.6 & 123 & 83.6 & 132 & 85 & 255 \\
\hline Yes & 13.4 & 19 & 16.5 & 26 & 15.0 & 45 \\
\hline Total & 100.0 & 142 & 100.0 & 158 & 100.0 & 300 \\
\hline \multicolumn{7}{|c|}{ Do your income from selling Agroforestry products/services? } \\
\hline No & 98 & 140 & 93.0 & 147 & 95.7 & 287 \\
\hline Yes & 2 & 2 & 7 & 11 & 4.3 & 13 \\
\hline Total & 100.0 & 142 & 100.0 & 158 & 100.0 & 300 \\
\hline \multicolumn{7}{|c|}{ Do you get income from business activities? } \\
\hline No & 83.1 & 49 & 83.5 & 66 & 83.3 & 115 \\
\hline Yes & 16.9 & 10 & 16.5 & 13 & 16.6 & 23 \\
\hline Total & 100.0 & 59 & 100.0 & 79 & 100.0 & 138 \\
\hline \multicolumn{7}{|c|}{ Do you get income from technical activities? } \\
\hline No & 90.9 & 50 & 100.0 & 64 & 95.8 & 114 \\
\hline Yes & 9.1 & 5 & 0 & 0 & 4.2 & 5 \\
\hline Total & 100.0 & 55 & 100.0 & 64 & 100.0 & 119 \\
\hline
\end{tabular}

Do you get income from hiring out non-agricultural labour within your locality?

\begin{tabular}{lcccccc}
\hline No & 100.0 & 52 & 100.0 & 63 & 100.0 & 115 \\
\hline Yes & 0 & 0 & 0 & 0 & 0 & 0 \\
\hline Total & 100.0 & 52 & 100.0 & 63 & 100.0 & 115
\end{tabular}

Do you get income from hiring out non-agricultural labour out-off your locality? (Remittance)

\begin{tabular}{lcccccc}
\hline No & 98.2 & 54 & 96.9 & 62 & 97.5 & 116 \\
\hline Yes & 1.8 & 1 & 3.1 & 2 & 2.5 & 3 \\
\hline Total & 100.0 & 56 & 100.0 & 64 & 100.0 & 119
\end{tabular}

Do you get income from other sources (grants and pension)?

\begin{tabular}{lcccccc}
\hline No & 3.5 & 5 & 10.1 & 16 & 7.0 & 21 \\
\hline Yes & 96.5 & 137 & 89.9 & 142 & 93.0 & 279 \\
\hline Total & 100.0 & 142 & 100.0 & 158 & 100.0 & 300 \\
\hline
\end{tabular}

Source: author, computed from survey data.

This study employs econometric analysis of determinants of livelihood strategies using a log linear regression model. The log linear regression model is specified as:

$$
\ln y_{i}=\beta_{0}+\beta_{1} x_{i 1}+\beta_{2} x_{i 2}+\ldots+\beta_{n} x_{i n}+\varepsilon_{i}
$$


where $y$ is the dependent variable, the $x^{\prime}$ s are independent variables and $\varepsilon$ is a stochastic error term. The subscript ' $i$ ' is the observation number from $n$ random observations. $\beta_{1 \text { through }} \beta_{k}$ are parameters that indicate the effect of a given $x$ on $y . \beta_{0}$ is the intercept which indicates the expected value of $y$ when all the $x^{\prime} s$ are 0 . The assumptions of the linear regression model are as follows:

- Linearity-according to Equation (1), y is linearly related to the $x$ 's through $\beta$ parameters.

- Colinearity-the x's are linearly independent. This means that none of the $x^{\prime} \mathrm{s}$ is a linear combination of the remaining $x^{\prime} s$.

- Zero condition mean of $\varepsilon$.

- Homoscedastic and uncorrelated Errors

- Normality

Equation (1) shows the model for the econometric analysis of determinants of livelihood strategies. The dependent variable, the natural logarithm of total sum of household income, is regressed on the independent variables: monetary value of annual income from crops and horticultural produce, dummy variable for farm production costs, monetary value of agroforestry products and services, natural logarithm of livestock size, and natural logarithm of household size, to find the standard regression coefficients. The beta weight $(\beta)$ of each of the independent variables, the multiple coefficients of determination, $R^{2}$, and the ANOVA results are shown in the following section. In this study, logarithmic transformations are used as a convenient means of transforming highly skewed variables into a more normalized dataset. In addition, the log transformation can decrease the variability of data and make data conform more closely to the normal distribution. Furthermore, a log transformation can help the sample observations better satisfy the assumptions of some statistical analysis mentioned above [43].

\section{Results and Discussion}

\subsection{Food Availability in the Study Areas}

Many South African households are food insecure. Estimated food-insecure households range from $50-80 \%$, depending on the criteria and survey data used, such as under nutrition or undernourishment, and income and expenditure, general household, or national food consumption surveys [44]. The drivers of household food insecurity include food prices; the amount of household income available for purchasing food, mediated by household size; the effectiveness of agricultural production as a source of food and/or income, mediated by access to land, soil quality, and access to credit and markets; as well as access to basic services, which affects health and nutritional requirements, food safety and the household income available for food instead of other livelihood costs, such as transport [42].

The Department of Agriculture has developed an Integrated Food Security Strategy, which identifies five priority areas of intervention: increasing household food production, increasing food trade and distribution, increasing income opportunities, improving nutritional status, and enhancing institutional support networks. However, implementation of this strategy requires the support of other important departments and spheres and, in the context of weaknesses in government coordination and institutional capacity, driving such an integrated approach remains a challenge. Moreover, the private sector can make a significant contribution to food security by helping to educate consumers through proper food labelling, maximising efficiencies to decrease food prices, supporting smallholder farmers to improve productivity and market access, and integrating small and medium enterprises (SMEs) into supplier and distribution value chains. However, progress to date has been limited. Furthermore, there is a monopoly structure present in the economy where almost every single staple in South Africa is already produced by large manufacturers that can produce it at better quality and lower cost than the average smallholder enterprise or cooperative. Such a monopoly structure fundamentally undermines the development of local markets where local small-scale producers sell to their local community. In this 
context, South Africa needs to develop a rural economy that not only sells to the poor but also works for the poor through developing local, community level food systems that allow for local markets and local beneficiation [44].

On average, for both study sites, 25 percent of the respondents confirmed that they have been facing food shortages in the last 10 years with the highest frequency from 7 to 10 times in those years with the highest average magnitude of 37.6 percent. To reverse such a scenario in rural food availability the South African government needs to learn from experiences of countries in southern Africa. Malawi's celebrated achievement in improving rural food production by prompting the smallholder agricultural sector is worth mentioning here. The Malawian Government's Agricultural Input Subsidy Program (AISP), with significant development support, has as its main objective, improving smallholder agricultural productivity, food, and cash crop production. Such intervention has reduced vulnerability to food insecurity and hunger and has resulted in increased crop productivity during the two years of its implementation, especially increases in maize production, which is a staple food for Malawians. In addition, Malawi was able to realize surpluses in maize production, allowing it to export to other countries in the region [20].

Figure 2 highlights food security challenges in South Africa. Increasing household food production is one of the priority areas of intervention.

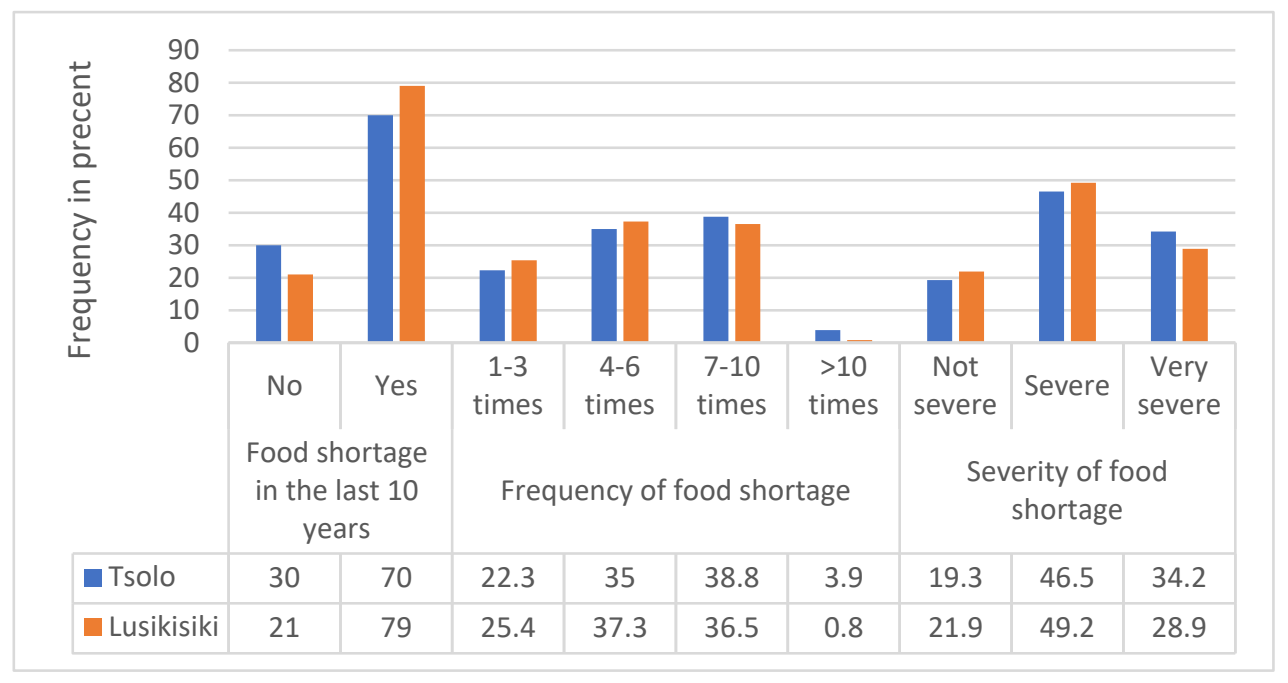

Figure 2. Availability, frequency, and severity of food shortage in the study areas. Source: author.

\subsection{Descriptive Analysis of Livelihood Activities in Study Areas}

Livelihood activities comprise the various activities that people perform on a dayto-day basis to make a living. As depicted in Figure 3, grants and pensions constitute the largest portion of household livelihood income. In total, 96.65 percent and 89.9 percent of the respondents confirmed that they get government transfers in Tsolo and Lusikisiki, respectively.

When we rank the rest of the livelihood activities in Tsolo, income from agricultural activities ranks first, second income from business activities (i.e., buying and selling of agricultural produce, nontimber forest products, and others), third income from livestock sells, fourth income from technical activities (i.e., hand crafts and small industry), fifth income from sell of agroforestry products/services, and sixth income from remittances from family members working in the urban areas. Similarly, in Lusikisiki, income from agricultural activities comes first, income from livestock sales and from business activities both stood second, income from the sale of agroforestry products or services comes forth, and then lastly income from remittances. However, here, we need to note that since valuation of agroforestry products and services are technically difficult, farmers often underestimate the contribution of agroforestry in the household livelihood income [5]. 
Table 1 presents the main sources of livelihood in Tsolo and Lusikisiki, respectively. Further light on this econometric analysis of the determinants of household livelihood activities is shed in Section 4.3.

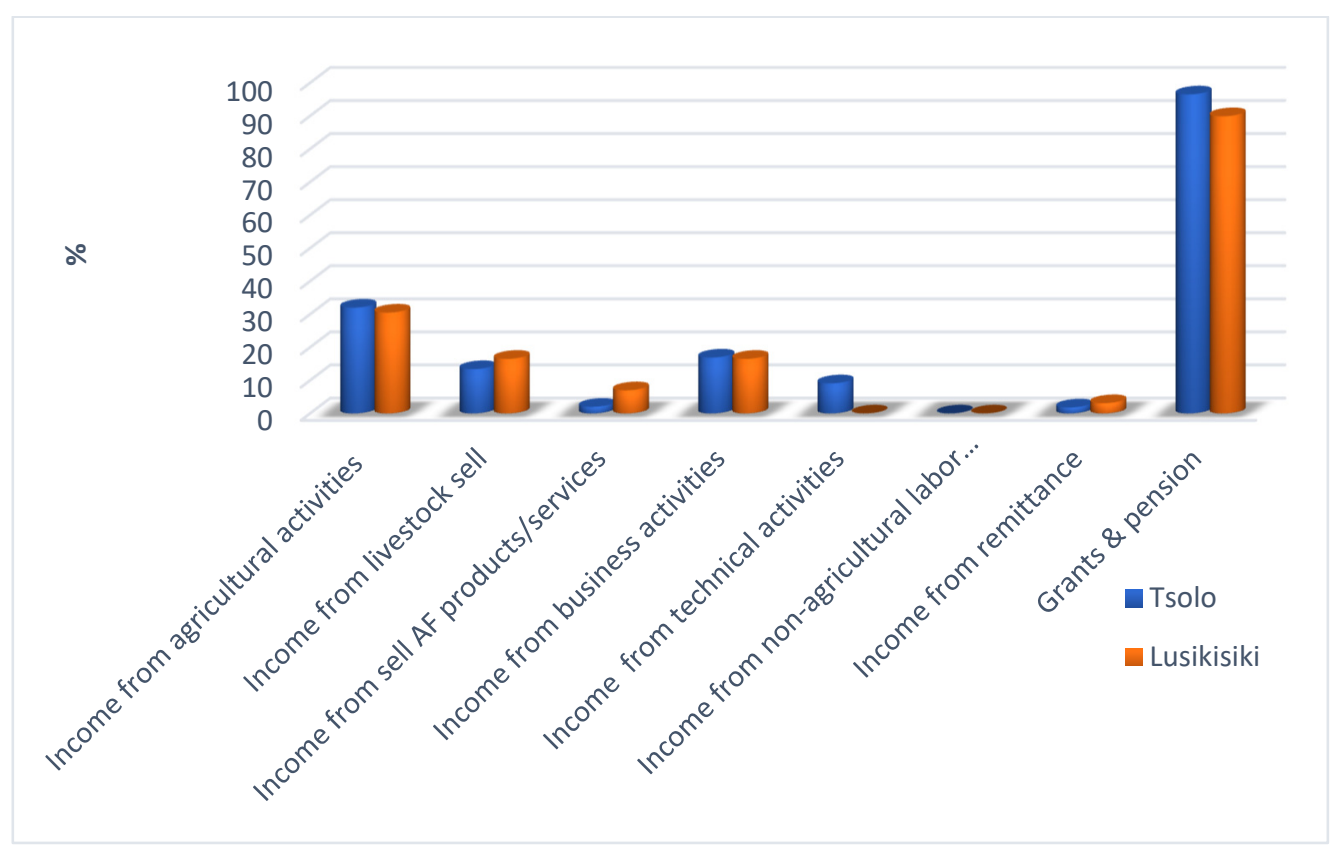

Figure 3. Main sources of livelihood in Tsolo and Lusikisiki, respectively.

\subsection{Econometric Results}

This section reports the impact of the adoption of agroforestry practices in improving the rural livelihood in Tsolo and Lusikisiki, respectively. In total, 78.3 percent of the respondents consider that agroforestry has been making and has the potential to make a sizeable contribution to improving the livelihood strategies of farming households. Table 2 summarises different ways in which forests and agroforests contribute towards household livelihood strategies.

Table 2. Ways how forests and agroforestry contribute toward household livelihood.

\begin{tabular}{|c|c|c|c|c|c|}
\hline \multicolumn{2}{|c|}{$\begin{array}{l}\text { Ways How Forests and Agroforestry } \\
\text { Contribute toward Household Livelihood }\end{array}$} & \multirow{2}{*}{$\begin{array}{c}\text { Frequency } \\
94\end{array}$} & \multirow{2}{*}{$\begin{array}{c}\text { Percent } \\
31.3\end{array}$} & \multirow{2}{*}{$\begin{array}{c}\text { Valid Percent } \\
34.2\end{array}$} & \multirow{2}{*}{$\begin{array}{c}\begin{array}{c}\text { Cumulative } \\
\text { Percent }\end{array} \\
34.2\end{array}$} \\
\hline \multirow{7}{*}{ Valid } & As a source of fuel wood & & & & \\
\hline & As source of fodder & 13 & 4.3 & 4.7 & 38.9 \\
\hline & Shade for animals & 27 & 9.0 & 9.8 & 48.7 \\
\hline & Source of construction materials & 26 & 8.7 & 9.5 & 58.2 \\
\hline & Source of food & 90 & 30.0 & 32.7 & 90.9 \\
\hline & Medicinal value & 24 & 8.0 & 8.7 & 99.6 \\
\hline & Other & 1 & 0.3 & 0.4 & 100.0 \\
\hline \multirow{3}{*}{ Missing } & Total & 275 & 91.7 & 100.0 & \\
\hline & System & 25 & 8.3 & & \\
\hline & Total & 300 & 100.0 & & \\
\hline
\end{tabular}

Note: Valid percent is the percent when missing data are excluded from the calculations. Source: author, computed from survey data.

In Table 3, the land size owned (the dummy variable for farm production costs which is whether the household applies chemical fertilisers or not), and the monetary value of agroforestry products and services are significant at one percent level of significance. A 10 percent increase in the size of land owned by the households included in the sample en- 
tails a decline of the log of the total sum of household income by 1.65 percent, holding other things constant. This can be due to the higher cost of bringing more land under cultivation. 10 unit increase in the application of chemical fertilizers increases farm production costs, which entails a 1.53 unit increase in the household's total income, holding other things constant. Similarly, holding other things constant, a 10 percent increase in the monetary value of agroforestry products and services can increase total household income by 3.2 percent. This indicates that even though the contribution by agroforestry establishments in Tsolo and Lusikisiki, respectively, are still very low, the potential contribution of agroforestry can significantly improve household income. As the F-stat shows, the regression model is acceptable and significant at one percent level of significance. The monetary value of agroforestry products and services, our variable of interest, has significantly contributed to the total sum of household income in the study areas at 1percent level of significance, as shown in Table 3.

Table 3. Regression results of the factors influencing the household's net income.

\begin{tabular}{|c|c|c|c|c|c|}
\hline \multirow{2}{*}{ Model } & \multicolumn{2}{|c|}{$\begin{array}{l}\text { Unstandardized } \\
\text { Coefficients }\end{array}$} & \multirow{2}{*}{$\begin{array}{c}\begin{array}{c}\text { Standardized } \\
\text { Coefficients }\end{array} \\
\text { Beta }\end{array}$} & \multirow{2}{*}{$\mathrm{t}$-Stat. } & \multirow{2}{*}{ Sig. } \\
\hline & B & Std. Error & & & \\
\hline (Constant) & 8.276 & 0.287 & & $28.836^{* * *}$ & 0.000 \\
\hline Land size owned & -0.113 & 0.039 & -0.165 & $-2.891^{* * *}$ & 0.004 \\
\hline $\begin{array}{l}\text { Natural logarithm of monetary value } \\
\text { of annual income from crops and } \\
\text { horticultural produces }\end{array}$ & 0.025 & 0.000 & 0.044 & 0.796 & 0.427 \\
\hline $\begin{array}{l}\text { Dummy Variable for farm } \\
\text { production costs }(1=\text { if use chemical } \\
\text { fertilizers, }=0 \text { otherwise })\end{array}$ & 0.300 & 0.106 & 0.153 & $2.834^{* * *}$ & 0.005 \\
\hline $\begin{array}{l}\text { Natural logarithm of monetary value } \\
\text { of agroforestry products and services }\end{array}$ & 0.0651 & 0.000 & 0.320 & $5.878^{* * *}$ & 0.000 \\
\hline Natural logarithm of livestock size & 0.071 & 0.052 & 0.080 & 1.370 & 0.172 \\
\hline Natural logarithm of household size & 0.186 & 0.137 & 0.075 & 1.360 & 0.175 \\
\hline
\end{tabular}

Dependent Variable: Natural Logarithm of the total sum of household income. Adjusted R Square: 0.157; Std. Error of the Estimate: 1.18566; F-stat: $10.179\left(0.000^{* * *}\right) .{ }^{* * *} 1 \%$ level of significance. Source: author, computed from survey data.

\section{Conclusions and Policy Implications}

In South Africa, there is a pressing need to promote smallholder agriculture to promote rural livelihoods, to ensure food security, to lower inflation in food prices, and to address widespread rural unemployment in the country. Studies have shown that the number of households engaging in subsistence agriculture as a main source of food and income is declining; however, there are underutilized agricultural resources in the former homeland communal areas of the country. Meanwhile, there is a rise in the number of households engaging in subsistence production as an extra source of food. Agroforestry has the potential to make a sizeable contribution in improving the livelihood strategies of farming households in the study areas in many ways.

This study confirmed that agroforestry in Tsolo and Lusikisiki is known as a source of food, fodder, fuel wood, construction materials, shade for animals, and for medicinal value. As discussed in Section 4, income from the sale of agroforestry products and services is among the many household livelihood strategies. Agroforestry products and services have contributed less than 10 percent of the total households' income among framers practicing agroforestry. However, the valuation of agroforestry products and services are technically difficult for farmers to quantify in terms of their tangible and intangible value. Therefore, farmers often underestimate the contribution of agroforestry in the mix of household livelihood income contribution. According to the econometric analysis, holding other things constant, if the monetary value of agroforestry products and services significantly increase the total household income at 1 percent level of significance. This 
indicates that even though the contribution of agroforestry in the study areas is still very low, the potential contribution of agroforestry can significantly improve household income. This result has an important policy implication in the government's actions in achieving sustainable rural development.

Agroforestry practices in rural South Africa are still under the traditional level of operation. To include scientific inputs from academic and research institutions to the existing agroforestry practices, the Department of Agriculture and Forestry should focus on assisting farmers and extension workers with cutting-edge scientific practices and information. Farmers' education would increase the adoption of improved agroforestry practices. Improving marketing and adding value to agroforestry raw products are critical for enhancing the livelihoods of farmers practicing agroforestry. Community-based institutional mechanisms are needed to help farmers acquire information and business skills, market produce, and promote quality. Local churches in the study areas can be mobilized to create awareness about the benefits of agroforestry practices.

Farmers need intensive extension services and training on agroforestry practices and benefits to overcome the limits of some current practices. When starting operations, smallholder framers often lack the skills to establish tree and shrub nurseries, pretreat the seeds, and carry out tree pruning activities. Moreover, extension strategies, including field schools, exchange visits and farmer training, are effective ways of disseminating needed information. Government intervention in promoting agroforestry with the proper institutional arrangements can provide opportunities for the government to work with small, often poor farmers, to facilitate the collective actions required for making agroforestry practices work for the rural poor in Tsolo and Lusikisiki and in the Eastern Cape Province at large.

Funding: This research received no external funding.

Institutional Review Board Statement: Not applicable.

Informed Consent Statement: Informed consent was obtained from all subjects involved in the study.

Data Availability Statement: Data are available upon request from the author.

Acknowledgments: The authors would like to express sincere gratitude to the anonymous reviewers for improving the quality of this paper. The author would also like extend his appreciation to Tsolo Agricultural and Rural Development Institute in the Eastern Cape Province, South Africa, for the generous logistic support during data collection at Tsolo and Lusikisiki. The usual disclaimer applies. The author would like to express his gratitude to the Faculty of Economics and Finance, Tshwane University of Technology for the payment of page fees.

Conflicts of Interest: The author declares no conflict of interest.

\section{References}

1. Zerihun, M.F.; Muchie, M.; Worku, Z. Determinants of agroforestry technology adoption in Eastern Cape Province, South Africa. Dev. Stud. Res. Open Access J. 2014, 1, 382-394. [CrossRef]

2. Sheppard, J.P.; Bohn Reckziegel, R.; BorrSass, L.; Chirwa, P.W.; Cuaranhua, C.J.; Hassler, S.K.; Hoffmeister, S.; Kestel, F.; Maier, R.; Mälicke, M.; et al. Agroforestry: An Appropriate and Sustainable Response to a Changing Climate in Southern Africa? Sustainability 2020, 12, 6796. [CrossRef]

3. Ahmed, S.; Caihong, Z.; Ekanayake, E.M.B.P. Livelihood Improvement through Agroforestry Compared to Conventional Farming System: Evidence from Northern Irrigated Plain, Pakistan. Land 2021, 10, 645. [CrossRef]

4. Oduniyi, O.S.; Tekana, S.S. Adoption of agroforestry practices and climate change mitigation strategies in North West province of South Africa. Int. J. Clim. Chang. Strateg. Manag. 2019, 11, 716-729. [CrossRef]

5. MacDicken, K.G.; Vergara, N.T. Agroforestry: Classification and Management; John Wiley and Sons: New York, NY, USA, 1990.

6. Rosati, A.; Borek, R.; Canali, S. Agroforestry and organic agriculture. Agrofor. Syst. 2021, 95, 805-821. [CrossRef]

7. Cooper, P.J.M.; Leakey, R.R.B.; Rao, M.R.; Reynolds, L. Agroforestry, and the mitigation of land degradation in the humid and sub-humid tropics of Africa. Exp. Agric. 1996, 32, 235-290. [CrossRef]

8. Sanchez, P.A. Science in agroforestry. Agrofor. Syst. 1995, 30, 5-53. [CrossRef]

9. Franzel, S.; Cooper, J.; Denning, G. Scaling up the benefits of agroforestry research: Lessons learned and research challenges. Dev. Pract. 2001, 11, 524-534. [CrossRef] 
10. Kang, B.T.; Akinnifesi, F.K. Agroforestry as alternative land-use production system for the tropics. Nat. Resour. Forum 2000, 24, 137-151. [CrossRef]

11. Neupane, R.P.; Thapa, G.B. Impact of agroforestry intervention on soil fertility and farm income under the subsistence farming system of the middle hills, Nepal. Agric. Ecosyst. Environ. 2001, 84, 157-167. [CrossRef]

12. Neupane, R.P.; Sharma, K.R.; Thapa, G.B. Adoption of agroforestry in the hills of Nepal: A logistic regression analysis. Agric. Syst. 2002, 72, 177-196. [CrossRef]

13. Tadesse, M.; Simane, B.; Abera, W.; Tamene, L.; Ambaw, G.; Recha, J.W.; Mekonnen, K.; Demeke, G.; Nigussie, A.; Solomon, D. The Effect of Climate-Smart Agriculture on Soil Fertility, Crop Yield, and Soil Carbon in Southern Ethiopia. Sustainability 2021, 13, 4515. [CrossRef]

14. Schoeneberger, M.M. Agroforestry: Working trees for sequestering carbon on agricultural lands. Agrofor. Syst. 2009, 75, 27-37. [CrossRef]

15. Lowe, W.A.M.; Sinniah, J.; Jeyavanan, K. 'Can homegardens assist in enhancing the domestic food security?' A study in Jaffna Peninsula, Sri lanka. Agrofor. Syst. 2021, 1-12. [CrossRef]

16. Pagiola, S. Payments for environmental services in Costa Rica. Ecol. Econ. 2008, 65, 712-724. [CrossRef]

17. Garrity, D.P. Science-based agroforestry and the millenium development goals. In World Agroforestry into the Future; Garrity, D.P., Okono, A., Grayson, M., Parrott, S., Eds.; World Agroforestry Centre, ICRAF: Nairobi, Kenya, 2006.

18. Race, D. Adoption of Agroforestry in Australia: Agroforestry for Natural Resource Management; CSIRO Publishing: Collingwood, Australia, 2009.

19. Sobola, O.O.; Amadi, D.C.; Jamala, G.Y. The Role of Agroforestry in Environmental Sustainability. J. Agric. Vet. Sci. 2015, 8, 2319-2372. [CrossRef]

20. Baiphethi, M.N.; Jacobs, P.T. The Contribution of Subsistence Farming to Food Security in South Africa; Centre for Poverty, Employment and Growth, Human Sciences Research Council: Pretoria, South Africa, 2009.

21. Duffy, C.; Toth, G.G.; Hagan, R.P.O. Agroforestry contributions to smallholder farmer food security in Indonesia. Agrofor. Syst. 2021, 1-16. [CrossRef]

22. Alao, J.S.; Shuaibu, R.B. Agroforestry practices and concepts in sustainable land use systems in Nigeria. J. Hortic. For. 2013, 5, 156-159.

23. Babulo, B.; Muys Nega, F.; Tollens, E.; Nyssen, J.; Deckers, J.; Mathijs, E. Household livelihood strategies and forest dependence in the highlands of Tigray, Northern Ethiopia. Agric. Syst. 2008, 98, 147-155. [CrossRef]

24. World Bank. Sustaining Forests: A Development Strategy; The World Bank: Washington, DC, USA, 2004.

25. Jama, B.; Zeila, A. Agroforestry in the Drylands of Eastern Africa: A Call to Action; ICRAF Working Paper-No. 1; World Agroforestry Centre: Nairobi, Kenya, 2006.

26. Alavalapati, J.R.R.; Mercer, D. (Eds.) Valuing Agroforestry Systems: Methods and Applications; Kluwer Academic Publishers: Dordrecht, The Netherlands, 2004.

27. Alavalapati, J.R.R.; Nair, P. Socioeconomics and institutional perspectives of agroforestry. In World Forests, Society and Environment Markets and Polices; Palo, M., Uusivuori, J., Eds.; Kluwer Academic Publishers: Dordrecht, The Netherlands, 2001.

28. Acheampong, E.; Insaidoo, T.F.G.; Ros-Tonen, M.A.F. Management of Ghana's modified taungya system: Challenges and strategies for improvement. Agrofor. Syst. 2016, 90, 659-674. [CrossRef]

29. Aragaw, H.S.; Nohr, D.; Callo-Concha, D. Nutritional potential of underutilized edible plant species in coffee agroforestry systems of Yayu, southwestern Ethiopia. Agrofor. Syst 2021, 1-13. [CrossRef]

30. Bulitta, B.J.; Duguma, L.A. The Unexplored Socio-Cultural Benefits of Coffee Plants: Implications for the Sustainable Management of Ethiopia's Coffee Forests. Sustainability 2021, 13, 3912. [CrossRef]

31. Koyejo, A.O.; Okpara, D.A.; Agugo, B.A.C. Effect of alley cropping on soil, maize and mungbean grown under different maize spatial arrangements and mungbean spacings in southeast Nigeria. Agrofor. Syst. 2021, 1-10. [CrossRef]

32. Brown, D.; Stephens, E.; Ouma, J.; Murithi, F.; Barrett, C. Livelihood strategies in the rural Kenyan highlands. Afr. J. Agric. Resour. Econ. 2006, 1, 21-36.

33. DFID. Sustainable Livelihoods Guidance Sheets; DFID: London, UK, 2001.

34. Ellis, F. Rural Livelihoods, and Diversity in Developing Countries; Oxford University Press: Oxford, UK, 2000.

35. Sati, V.P.; Vangchhia, L. Introduction. In A Sustainable Livelihood Approach to Poverty Reduction; Springer Briefs in Environmental Science; Springer: Berlin/Heidelberg, Germany, 2017. [CrossRef]

36. Su, Z.; Aaron, J.R.; Guan, Y.; Wang, H. Sustainable Livelihood Capital and Strategy in Rural Tourism Households: A Seasonality Perspective. Sustainability 2019, 11, 4833. [CrossRef]

37. Sun, H.; Hartarska, V.; Zhang, L.; Nadolnyak, D. The Influence of Social Capital on Farm Household's Borrowing Behavior in Rural China. Sustainability 2018, 10, 4361. [CrossRef]

38. Narayan, D. Voices of the Poor: Poverty and Social Capital in Tanzania; ESSD Studies and Monographs Series; The World Bank: Washington, DC, USA, 1997; Volume 20.

39. Jeremy, H. Tools for Institutional, Political, and Social Analysis of Policy Reforms: A Source Book for Development Practitioners; The World Bank: Washington, DC, USA, 2007.

40. Masubelele, M.L.; Hoffman, M.T.; Bond, W.J. Biome stability and long-term vegetation change in the semi-arid, south-eastern interior of South Africa: A synthesis of repeat photo-monitoring studies, South African. J. Bot. 2015, 101, 139-147. [CrossRef] 
41. Li, R.Y.M.; Chau, K.W.; Zeng, F.F. Ranking of Risks for Existing and New Building Works. Sustainability 2019, 11, 2863. [CrossRef]

42. Li, R.Y.M.; Tang, B.; Chau, K.W. Sustainable Construction Safety Knowledge Sharing: A Partial Least Square-Structural Equation Modeling and A Feedforward Neural Network Approach. Sustainability 2019, 11, 5831. [CrossRef]

43. Curran-Everett, D. Explorations in statistics: The log transformation. Adv. Physiol. Educ. 2018, 42, 343-347. [CrossRef] [PubMed]

44. Boraine, Andrew. Prospects for South Africa's Future; Development Report 2011: Overview; DBSA: Pretoria, South Africa, 2011. Available online: www.dbsa.org (accessed on 12 December 2020). 